\title{
CORRECTION
}

\section{Correction: Long-term outcomes of the GPOH NB97 trial for children with high-risk neuroblastoma comparing high-dose chemotherapy with autologous stem cell transplantation and oral chemotherapy as consolidation}

Frank Berthold ${ }^{1}$, Angela Ernst ${ }^{2}$, Barbara Hero ${ }^{1}$, Thomas Klingebiel ${ }^{3}$, Bernhard Kremens ${ }^{4}$, Freimut H. Schilling ${ }^{5}$ and Thorsten Simon ${ }^{1}$ British Journal of Cancer (2019) 121:894-895; https://doi.org/10.1038/s41416-019-0592-5

Correction to: British Journal of Cancer (2018) 119, 282-290; https:// doi.org/10.1038/s41416-018-0169-8; published online 11 July 2018.

The authors have noticed in Table 4 that the MT and $P$-value columns which should have appeared below the heading 'Late sequelae independent of recurrent timepoint' have erroneously been listed under the 'Late sequelae before recurrence' heading. The correct format of Table 4 is shown below.

\begin{abstract}
(c) (i)
Open Access This article is licensed under a Creative Commons Attribution 4.0 International License, which permits use, sharing, adaptation, distribution and reproduction in any medium or format, as long as you give appropriate credit to the original author(s) and the source, provide a link to the Creative Commons license, and indicate if changes were made. The images or other third party material in this article are included in the article's Creative Commons license, unless indicated otherwise in a credit line to the material. If material is not included in the article's Creative Commons license and your intended use is not permitted by statutory regulation or exceeds the permitted use, you will need to obtain permission directly from the copyright holder. To view a copy of this license, visit http://creativecommons. org/licenses/by/4.0/.
\end{abstract}

(c) The Author(s) 2019

${ }^{1}$ Children's Hospital, University of Cologne, Cologne, Germany; ${ }^{2}$ Institute of Medical Statistics and Bioinformatics, University of Cologne, Cologne, Germany; ${ }^{3}$ Children's Hospital, University of Frankfurt, Frankfurt, Germany; ${ }^{4}$ Children's Hospital, University of Essen, Essen, Germany and ${ }^{5}$ Children's Hospital, Olgahospital, Stuttgart, Germany

Correspondence: Frank Berthold (frank.berthold@uk-koeln.de)

Published online: 24 September 2019 


\begin{tabular}{|c|c|c|c|c|c|c|}
\hline Late sequelae & \multicolumn{3}{|c|}{$\begin{array}{l}\text { Late sequelae independent of recurrence } \\
\text { timepoint }\end{array}$} & \multicolumn{3}{|c|}{ Late sequelae before recurrence ${ }^{a}$} \\
\hline Intention to treat & $\%$ of 149 & $\%$ of 146 & & $\%$ of 149 & $\%$ of 146 & \\
\hline Auditory impairment & 25 & 20 & 0.330 & 20 & 13 & 0.118 \\
\hline Focal nodular hyperplasia of the liver & 6 & 1 & 0.019 & 6 & 1 & 0.019 \\
\hline Hepatopathy & 4 & 1 & 0.121 & 3 & 1 & 0.214 \\
\hline Peripheral neuropathy & $<1$ & $<1$ & 1.000 & 0 & $<1$ & 0.244 \\
\hline Growth retardation & 2 & 3 & 0.721 & 1 & 3 & 0.444 \\
\hline Cardiomyopathy & 0 & 2 & 0.120 & 0 & 2 & 0.120 \\
\hline As treated & $\%$ of 110 & $\%$ of 102 & & $\%$ of 110 & $\%$ of 102 & \\
\hline Auditory impairment & 31 & 21 & 0.116 & 21 & 19 & 0.732 \\
\hline Renal impairment & 8 & 11 & 0.640 & 6 & 9 & 0.606 \\
\hline Thyroid dysfunction & 12 & 7 & 0.247 & 11 & 7 & 0.344 \\
\hline Focal nodular hyperplasia of the liver & 6 & 1 & 0.067 & 6 & 1 & 0.067 \\
\hline Hepatopathy & 3 & 1 & 0.623 & 3 & 1 & 0.623 \\
\hline Peripheral neuropathy & $<1$ & 0 & 1.000 & $<1$ & 0 & 1.000 \\
\hline Growth retardation & 2 & 1 & 1.000 & 2 & 1 & 1.000 \\
\hline Cardiomyopathy & 0 & 2 & 0.230 & 0 & 2 & 0.230 \\
\hline Residual transverse myelopathy & 0 & 1 & 0.481 & 0 & 1 & 0.481 \\
\hline Persisting thrombocytopenia & $<1$ & 0 & 1.000 & $<1$ & 0 & 1.000 \\
\hline Hepatopathy & 4 & 1 & 0.621 & 4 & 1 & 0.621 \\
\hline Peripheral neuropathy & 1 & 0 & 1.000 & 0 & 0 & n.a \\
\hline Growth retardation & 0 & 1 & 0.483 & 0 & 1 & 0.483 \\
\hline Cardiomyopathy & 0 & 3 & 0.231 & 0 & 3 & 0.231 \\
\hline Residual transverse myelopathy & 0 & 1 & 0.483 & 0 & 1 & 0.483 \\
\hline Persisting thrombocytopenia & 0 & 0 & N.A. & 0 & 0 & N.a. \\
\hline Visual impairment & 3 & 3 & 1.000 & 3 & 3 & 1.000 \\
\hline
\end{tabular}

